\title{
Pre-revolutionary Russian Universities in Modern Historiography
}

\author{
M. V. Gribovskiy
}

For citation: Gribovskiy M.V. Pre-revolutionary Russian Universities in Modern Historiography. Vestnik of Saint Petersburg University. History, 2019, vol. 64, issue 1, pp. 192-210. https://doi. org/10.21638/11701/spbu02.2019.111

The article focuses on the main trends in Russian and foreign historiography of Russian universities at the turn of the $20^{\text {th }}$ century to identify the most promising directions for research. The author suggests that the current stage of historical and university research be counted from the 1980s-1990s. Though historiography of the 1990s was quick to abandon ideological clichés, it inherited a range of approaches, problems, and conclusions from the past. Having examined a number of summarizing monographs on the history of Russian education and theory of university research, the author assumes that the 2000s witnessed a certain "social turn" with its profound attention to the "human dimension" of the university's past. The most topical and promising trends in historiography of Russian universities include the study of intra-corporate relations in various universities, "university conflictology", academic mobility and dissertation ethics in Russia, professorial daily life and leisure, etc. Drawing on works of foreign historiographers, Russian historiographers should abandon the formal approach limited by state borders. It is suggested that the works by Ukrainian, Polish, Estonian and other researchers from the countries where some universities of the former Russian Empire are located should be viewed as a separate group. It is also noted that, unlike Russian historiographical tradition, the West European and American framework in the $20^{\text {th }}$ century was not discrete by its nature and retained its traditional interest in the problem of relationships between universities (i.e. academic community and students) and Russian society. In conclusion, the author points out the anthropocentric approach as very valuable for the studies of university history.

Keywords: Russian universities, turn of the $20^{\text {th }}$ century, historiography, social history, anthropocentric approach.

Mikhail V. Gribovskiy - PhD in History, Associate Professor, Tomsk State University, 36, Lenin pr., Tomsk, 634050, Russian Federation; mgrib@mail2000.ru

Михаил Викторович Грибовский - канд. ист. наук, доц., Национальный исследовательский Томский государственный университет, Российская Федерация, 634050, Томск, пр. Ленина, 36; mgrib@mail2000.ru

Исследование выполнено при поддержке гранта Российского научного фонда, проект № 18-18-00121.

This research was supported by Russian Science Foundation, project № 18-18-00121.

(C) Санкт-Петербургский государственный университет, 2019 


\section{Дореволюционный российский университет в современной историографии}

\section{М.В. Грибовский}

Для цитирования: Gribovskiy M. V. Pre-revolutionary Russian Universities in Modern Historiography // Вестник Санкт-Петербургского университета. История. 2019. Т. 64. Вып. 1. С. 192-210. https://doi.org/10.21638/11701/spbu02.2019.111

Статья посвящена выявлению основных тенденций в отечественной и зарубежной историографии, касающейся российского университета рубежа XIX-XX вв., и определению наиболее перспективных направлений дальнейших исследований. Особое внимание уделено исследованиям университетской профессуры конца имперского периода. Современный этап историко-университетских исследований предлагается отсчитывать с рубежа 1980-х - 1990-х годов, когда в России с изменениями политического строя стали меняться и подходы к изучению университетского прошлого. Отмечается инерционность историографии 1990-х годов, которая хотя и быстро избавилась от идеологических клише, но унаследовала от прошлого подходы и круг проблем, а порой и выводы. Анализируются обзорно-обобщающие труды по истории образования в России, а также исследования, представляющие собой теоретическое осмысление университетского прошлого. Подчеркивается, что в 2000-е годы наметился «социальный поворот», сопровождаемый большим вниманием к «человеческому измерению». К актуальным и перспективным отечественным исследованиям отнесены: изучение внутрикорпоративных отношений преподавателей различных университетов, «университетская конфликтология», изучение академической мобильности, диссертационной культуры в дореволюционной России, проблемы профессорской повседневности и досуга и др. Предлагается, обращаясь к зарубежной историографии, отказаться от формального подхода, предусматривающего ориентацию исключительно на государственные границы. По мнению автора, к отдельной группе следует отнести работы украинских, польских и эстонских историков как исследователей из тех стран, где расположены некоторые университеты бывшей Российской империи. Отмечается, что западноевропейская и американская историография в XX в. не носила такого дискретного характера, как историография отечественная и постсоветская, и сохранила характерный для более раннего времени интерес к проблеме взаимоотношений университета (в лице ученого сообщества и студенчества) и русского общества. Делается вывод о перспективах антропоцентрического подхода к изучению университетской истории.

Ключевые слова: российские университеты, рубеж XIX-XX вв., историография, социальная история, антропоцентрический подход.

The history of Russian pre-revolutionary universities is traditionally measured by the four University Statutes adopted in the $19^{\text {th }}$ century. Following this logic, 1884 signified the final period in the development of Russian universities, which began with the adoption of the last University Statute regulating the life of the classical higher school, and ended with the revolutionary changes in February 1917, thus terminating the Russian Empire and the imperial university system.

The turn of the $20^{\text {th }}$ century was the heyday of Russian universities when they were recognised as European centres for science and education, and when the professoriate began to play a significant role in the life of university cities as well as in the political life of the entire country.

Over the past 130 years Russian historiography has formed a broad research tradition of studying Russian universities, which means that historiographers have to deal with 
thousands of research papers, not to mention those on the development of university science.

This article focuses on the main trends in Russian and foreign historiography of Russian universities at the turn of the $20^{\text {th }}$ century to identify the most promising among them.

The current stage of historical and university research began in the 1980s-1990s, when changes in the Russian political system affected the approaches to the studies of the university's past. However, it is a rare case when historiographic tendencies chronologically coincide with political changes, either anticipating or lagging behind the latter. Unlike journalistic works, a serious historical research may last for many years before it is published, which explains a slow responsive character of historiography of the turning epochs.

This assertion fully applies to Russian historiography of Russian university in the 1990 s and, in part, in the 2000s, which has already been in the focus of scholarly interest ${ }^{1}$. Though the historiographers were quick to abandon ideological clichés, they inherited a range of approaches, problems, and sometimes conclusions from the past ${ }^{2}$.

There are numerous works on the political history of universities (A.E. Ivanov, A.L. Litvin, V.L. Markin, S.A. Nekrylov, E.A. Rostovtsev, S. F. Fominykh, A. V.Sharova), however, it should be noted that the overwhelming majority of Russian researchers tend to side up with the "progressive" liberal professorship opposed to the government. Rare exceptions include the works by V.S. Brachev on the history of St. Petersburg University self-government, student protests, and relationship between professorial corporations and power ${ }^{3}$; on the history of university institutions (L. V. Golovko, T. I. Eremin, E. A. Zagorulko, N. V. Ilyutchenko, V. V. Suyazova) ${ }^{4}$; departments (A. Yu. Dvornichenko, N. F. Kozy-

${ }^{1}$ Lapteva L.P. Istoriia rossiiskikh universitetov XVIII — nachala XX veka v noveishei otechestvennoi literature (1985-1999 gody) // Rossiiskie universitety v XVIII-XX vv. Iss. 5. Voronezh, 2000. P. 4-27; Sosnitskii D. A. Osnovnye napravleniia izucheniia istorii Sankt-Peterburgskogo universiteta v sovremennoi rossiiskoi istoriografii // Klio. 2017. No. 10 (130). P.207-217.

${ }^{2}$ See, for example: Vuchinich A. Russkaia nauka v epokhu krizisa: 1890-1910 gg. // Voprosy istorii estestvoznaniia i tekhniki. 1993. No. 3. P.3-28; Zmeev V. A. Universitetskii ustav 1884 g. // Sotsial'no-politicheskii zhurnal. 1998. No. 6. P.139-154; Romanov Iu.V. Nauka i vlast': nasledie L. A. Kasso // Trudy nauchnoi konferentsii studentov i aspirantov "Lomonosov-99". Istoriia. M., 1999. P.76-80; Iablokov S. A. Iuridicheskii fakul'tet Moskovskogo universiteta posle vvedeniia universitetskogo Ustava 1884 g. // Vestnik of Moscow University. Ser. 11. Pravo. 2006. No. 5. P. 113-126.

3 See: Ivanov A.E : 1) Rossiiskoe "uchenoe soslovie" v gody "Vtoroi Otechestvennoi voiny" (Ocherk grazhdanskoi psikhologii i patrioticheskoi deiatel'nosti) // Voprosy istorii estestvoznaniia i tekhniki. 1999. No. 2. P. 108-127; 2) V preddverii kadetskoi partii: vserossiiskii soiuz deiatelei nauki i vysshei shkoly // Vlast' i nauka, uchenye i vlast': 1880-e - nachalo 1920-kh godov: materialy Mezhdunarodnogo nauchnogo kollokviuma. SPb., 2003. P. 202-212; Litvin A. L. Uchenye Kazanskogo universiteta vo vremia smeny politicheskikh rezhimov // Ibid. P. 124-132; Markin V. L. Studenty i prepodavateli Moskovskogo universiteta v obshchestvenno-politicheskoi zhizni Rossii nachala XX veka: diss. ... kand. ist. nauk. M., 2009; Rostovtsev E. A. Akademicheskaia korporatsiia Sankt-Peterburgskogo universiteta $\mathrm{v}$ nachale XX v.: otnoshenie $\mathrm{k}$ vlasti i grazhdanskomu obshchestvu // "Byt' russkim po dukhu i evropeitsem po obrazovaniiu": Universitety Rossiiskoi imperii v obrazovatel'nom prostranstve Tsentral'noi i Vostochnoi Evropy XVIII — nachala XX v. M., 2009. P. 139-156; Sharova A. V. Universitetskoe soobshchestvo i vlast' v nachale XX veka (po materialam dnevnikovykh zapisei A.N. Savina) // Vestnik of the Russian State University for the Humanities. 2010. No. 18. P.270-287; Fominykh S. F., Nekrylov S. A. Neugodnyi vlastiam professor: kak uvol'niali I. A. Malinovskogo iz Imperatorskogo Tomskogo universiteta // Chasopis Natsional'nogo universitetu "Ostroz'ka akademiia”. Ser. Pravo. 2012. No. 2 (6). URL: http://l.oa.edu.ua/articles/2012/n2/12fsfitu.pdf (accessed 10.06.2018).

${ }^{4}$ Golovko L. V., Il'iutchenko N. V. Professorskii distsiplinarnyi sud pri Imperatorskom Moskovskom universitete // Vestnik of Moscow University. Ser. 11. Pravo. 2004. No. 6. P.94-110; Zagorul'ko E. A. Profes- 
renko, N. V. Kaledin) ${ }^{5}$ or personalities (A. V. Antoshchenko, M.A. Balyshev, E. S. Dosekin, E. D. Frolov, D. A. Tsygankov, I. V. Cherkazyanova) ${ }^{6}$.

The mid-1990s saw the revival of the pre-revolutionary tradition of biographical dictionaries of Russian university professors. Though such editions usually qualify as reference books, some of them appear to be full-fledged researches in terms of their content.

During the period under analysis, there appeared new versions of biographical dictionaries of Moscow, St. Petersburg and Kazan universities ${ }^{7}$, as well as first editions of such dictionaries of Kharkov, Novorossiysk, Tomsk, Saratov, and Perm universities ${ }^{8}$. A remarkable achievement of historiography was the book "Professors of Tomsk University. A Biographical Dictionary. Issue. 1. 1888-1917” published in Tomsk, in 1996, where each article is a deep biographical study including not only general information (years of life, place of birth and death, Alma Mater), but also the detailed information on parents and family, research activities, mentors and students, followed by the list of major works.

sorskie distsiplinarnye sudy v vuzakh Sankt-Peterburga (1907-1914 gody) // Izbrannye tezisy dokladov III Studencheskoi sotsiologicheskoi mezhvuzovskoi konferentsii. SPb., 2012. P. 28-30; Eremina T. I. O poriadke deloproizvodstva v universitetskikh sudakh v otnoshenie studentov (na primere Sankt-Peterburgskogo i Kazanskogo universitetov) // Istoriko-pravovye problemy: novyi rakurs: sbornik nauchnykh rabot. Iss. 9-1. Kursk, 2014. P. 57-63; Suiazov V. V. Professorskii distsiplinarnyi sud v vuzakh Rossiiskoi Imperii // Vestnik of Science and Education. 2015. No. 5 (7). P. 101-105.

${ }^{5}$ Kozyrenko N.F. Istoriia al'gologii na kafedre botaniki biologo-pochvennogo fakul'teta // Vestnik of Saint-Petersburg University. Ser. 3. 2005. Iss. 2. P.62-70; Dvornichenko A. Yu. Kafedra istorii Rossii s drevneishikh vremen do nachala XX veka // Institut istorii Sankt-Peterburgskogo gosudarstvennogo universiteta segodnia. K 80-letiiu osnovaniia Istoricheskogo fakul'teta LGU-SPbGU. SPb., 2014. P. 29-37; Kale$\operatorname{din~N.~V.~Obshchestvennaia~geografiia~v~Sankt-Peterburgskom~universitete:~istoki~i~etapy~razvitiia~//~Vest-~}$ nik of Saint-Petersburg University. Ser. 7. 2015. No. 1. P.58-74; Dvornichenko A.Iu., Rostovtsev E. A., Barinov D. A. The department of Russian history at St. Petersburg university (1821-1917): a group portrait // Vestnik of Saint-Petersburg University. History. 2016. Iss. 3. P. 46-56.

${ }^{6}$ Frolov E. D. Nemetskii professor v russkom universitete: Ernst Romanovich fon SHtern (1859-1924) // Problemy sotsial'noi istorii i kul'tury srednikh vekov i rannego novogo vremeni. 2001. No. 3. P. 29-52; Tsygankov D. A. Professor Moskovskogo universiteta V. I. Ger'e (1837-1919) // Novaia i noveishaia istoriia. 2002. No. 5. P.219-230; Cherkaz'ianova I. V. Aleksandr Nikolaevich Shvarts: okruzhenie, vospriiatie, otsenki // Charkivs'kii istoriografichnii zbirnik. Iss. 7. Charkiv, 2004. P. 84-94; Balyshev M. A. Professor istorii Mikhail Vasil'evich Klochkov. Dokumental'no-biograficheskii ocherk // UNIVERSITATES. Nauka i prosveshchenie (Khar'kov). 2005. No. 2. P. 18-29; Tsygankov D. A. V.I. Ger'e i Moskovskii universitet ego epokhi (vtoraia polovina XIX - nachalo XX v.). M., 2008; Dosekin E. S. Evgenii Nikolaevich Trubetskoi: obshchestvennyi i politicheskii deiatel'. Samara, 2014; Antoshchenko A. V. Professor imperatorskogo Moskovskogo universiteta Pavel Gavrilovich Vinogradov (ocherki zhizni i deiatel'nosti). M., 2015.

7 Dekany Kazanskogo meditsinskogo universiteta: (ot meditsinskogo do meditsinskogo universiteta): Biograficheskii slovar' dekanov Kazanskogo gosudarstvennogo meditsinskogo universiteta. Kazan', 1997; Levshin L. V. Dekany fizicheskogo fakul'teta Moskovskogo universiteta. M., 2002; Professora Sankt-Peterburgskogo gosudarstvennogo universiteta. Biobibliograficheskii slovar'. SPb., 2004; Professora Moskovskogo universiteta. 1755-2004. Biograficheskii slovar'. Vol. 1-2. M., 2005; Setevoi biograficheskii slovar' professorov i prepodavatelei Sankt-Peterburgskogo universiteta (1819-1917). URL: http: // bioslovhist.history. spbu.ru/biografika/pp1.html (accessed 04.06.2018).

${ }^{8}$ Professora Tomskogo universiteta. Biograficheskii slovar'. Iss. 1. 1888-1917. Tomsk, 1996; Professora i doktora nauk Saratovskoi oblasti, 1909-1999. Bibliograficheskii spravochnik. In 8 vols. Vol. 1. 1909-1917. Saratov, 2000; Profesori Odes'kogo (Novorosijs'kogo) universitetu. Biografičnij slovnik. Vol. 1-4. Odessa, 2000; Professora Permskogo gosudarstvennogo universiteta (1916-2001). Perm', 2001; Biobibliograficheskii slovar' uchenykh Khar'kovskogo universiteta (1805-2004). Vol.1. Khar'kov, 2004; Kostitsyn V.I. Rektory Permskogo universiteta. 1916-2006. Perm', 2006; Fominykh S. F., Nekrylov S. A., Gribovskiy M. V., Mendrina G.I., Vengerovskii A.I., Novitskii V. V. Professora meditsinskogo fakul'teta Imperatorskogo (gosudarstvennogo) Tomskogo universiteta - Tomskogo meditsinskogo instituta - Sibirskogo gosudarstvennogo meditsinskogo universiteta (1878-2003). Biograficheskii slovar'. Vol.1-2. Tomsk, 2013. 
Since the late 1990s, various research teams have been working on summarizing works on the history of Russian education. The book edited by the Minister of General and Vocational Education V. G. Kinelev was the first post-Soviet experience of a systematic description of the history of higher education in pre-revolutionary Russia. Only one chapter in the book focuses directly on universities, with the whole emphasis laid on the government policy on higher education, organization of educational process, and training of the academic staff ${ }^{9}$. The same range of topics is discussed in the works by a Moscow professor V.A.Zmeev, whose monograph dwells on the development of the national higher school in the imperial period ${ }^{10}$.

Apparently valuable are relatively small, yet very informative historical essays by a Saratov researcher A. I. Avrus. Unlike the two above-mentioned works, this research exclusively concentrates on Russian universities, which makes it the first attempt in Russian historiography to systematically analyse the university history from its start to the late 20 th century. In her overview, the author divides the history of universities into three periods (pre-revolutionary, Soviet, and post-Soviet). The book is organised into chronological chapters, with sections 3.2 "A new attempt to limit university self-government", 4.1 "Universities on the eve of and during the first Russian revolution" and 4.2 "Between the two revolutions" being of a particular interest because in these chapters A. I. Avrus traces the development of various aspects of university life under the new Statute and political realities of the early $20^{\text {th }}$ century ${ }^{11}$.

Somewhat less informative and novel are the teaching aids, although there are exceptions among them, too. The most original is the series of lectures Universities and University Traditions in Russia by T. N. Zhukovskaya. In addition to such familiar aspects as educational processes, university system and academic degrees, she pays much attention to the everyday life of Russian nineteenth-century universities, studied within the context of European educational tradition. T. N.Zhukovskaya focuses on the problem of relationship between university and city and examines the architecture of university buildings, university holidays and folklore. She creates a portrayal of the university professor in terms of their social and professional status, and financial position ${ }^{12}$.

The work published by Moscow State University of Civil Engineering is based on series of lectures, with a little more than 20 pages devoted to the period under analysis. The authors provide a concise description of the educational process after the adoption of the new University Statute, outlining the university everyday life. They point out that "the interference of government officials in the university academic life caused indignation among professors and sometimes led to rather acute conflicts"13.

The least successful were the textbooks by a St. Petersburg researcher N. K. Gurkina ${ }^{14}$. Covering a ten-century period of the national education history, they provide a rather

\footnotetext{
9 Vysshee obrazovanie v Rossii: ocherk istorii do 1917 goda. M., 1995.

10 Zmeev V. A. Evoliutsiia vysshei shkoly Rossiiskoi imperii. M., 1998.

11 Avrus A. I. Istoriia rossiiskikh universitetov: ocherki. M., 2001.

12 Zhukovskaia T. N. Universitety i universitetskie traditsii v Rossii. Kurs lektsii. Petrozavodsk, 2011.

13 Ocherki istorii universitetskogo obrazovaniia. M., 2011. P. 88.

14 Gurkina N. K.: 1) Istoriia obrazovaniia v Rossii (X-XX veka): uchebnoe posobie. SPb., 2001; 2) Istoriia obrazovatel'nykh uchrezhdenii v Rossii (X-XX veka): uchebnoe posobie. SPb., 2012.
} 
sketchy outline of historical sources and contain factual errors, which has already been noted in historiographical literature ${ }^{15}$.

Of particular interest are the theoretical studies of the university's past. The works by A. Yu. Andreev (Moscow University) and S. I. Posokhov (Kharkov University) discuss the national university model and the evolution of the university idea in the Russian Empire. Some of their works are based on the sources of the $18^{\text {th }}-$ the first half of the $19^{\text {th }}$ century ${ }^{16}$.

Joint efforts of the Moscow and Kharkov schools of history resulted in the anthology University Idea in the Russian Empire of the $18^{\text {th }}-$ Early $20^{\text {th }}$ Centuries ${ }^{17}$, preceded by a program article "The National Model of University Education: On Emergence and Development" by A. Yu. Andreev, who focused on the continuity of the university idea in Russia and its correlation with the German and European tradition ${ }^{18}$.

The article centres on the concept of "university model", which includes university structure, principles of its functioning, and mechanisms for its expansion and interaction with other institutions in the educational space ${ }^{19}$. Taking the classical German university model as the starting point, A. Yu. Andreev defines the "national model" as the interaction of the classical university with the state system and educational policy. Referring to the turn of the $20^{\text {th }}$ century, he concludes that it was the spirit of corporatism inhereted by Russian universities from the pre-classical era that turned the life of professors into the struggle of factions and political parties towards the end of Imperial Russia. In general, A. Yu. Andreev believes that the national model of the Russian pre-revolutionary university combines pre-classical (medieval) and classical (German) elements: the former include corporatism and university privileges, while the latter - the ideals of pure science. This idea was also reflected upon in his later works ${ }^{20}$.

The first decade of the $21^{\text {st }}$ century was marked with a heated discussion about the Russian national model of higher education. An alternative position was set forth in a series of publications by a group of authors led by Professor E. V. Olesiyuk. They oppose the "Russian model and West European models of education, insisting on the fact that the national higher school went its own way which was fundamentally different from the western one, so this experience brought about a number of significant advantages ${ }^{21}$. As I

15 Kostina T. V. Retsenziia: Gurkina N. K. Istoriia obrazovatel'nykh uchrezhdenii v Rossii (X-XX veka). SPb.: Poltorak, 2012 // Istoricheskaia Ekspertiza. 2014. No. 1. P. 167-170.

16 Andreev A. Yu.: 1) Lektsii po istorii Moskovskogo universiteta. 1755-1855. M., 2001; 2) Rossiiskie universitety XVIII - pervoi poloviny XIX veka v kontekste universitetskoi istorii Evropy. M., 2009; Andreev A. Yu., Posokhov S. I. Universitet v Rossiiskoi Imperii XVIII - pervoi poloviny XIX veka. M., 2012.

17 Universitetskaia ideia v Rossiiskoi imperii XVIII — nachala XX veka: antologiia. M., 2011.

18 Andreev A. Yu. "Ideia universiteta" v Rossii (XVIII - nachalo XX v.) // "Byt' russkim po dukhu i evropeitsem po obrazovaniiu": Universitety Rossiiskoi imperii v obrazovatel'nom prostranstve Tsentral'noi i Vostochnoi Evropy XVIII — nachala XX v. M., 2009. P.9-31.

19 Andreev A. Yu. "Natsional'naia model" universitetskogo obrazovaniia: vozniknovenie i razvitie // Vysshee obrazovanie v Rossii. 2005. No. 1. P.156-169; No. 2. P.110-119.

${ }^{20}$ Andreev A. Yu.: 1) Sushchestvoval li "russkii put" razvitiia universitetov? // Vysshee obrazovanie v Rossii. 2008. No. 7. P. 113-119; 2) O "novom prochtenii" istorii rossiiskikh universitetov // Vysshee obrazovanie v Rossii. 2009. No. 3. P. 156-169.

${ }^{21}$ Dines V.A., Oleseiuk E. V., Shulus A.A. Ocherki po istorii i teorii otechestvennoi vysshei shkoly. Saratov, 2002; Oleseiuk E. V., Kruglov Iu.G., Dianova V.Iu., Nasonkin V. V., Chistokhvalov V.N. Rossiiskaia vysshaia shkola (ocherki istorii): ucheb. posobie. Vol. 1. Istoki i razvitie do 1917 g. M., 2005; Kruglov Iu. G., Oleseiuk E. V., Shulus A.A. Universitetskie ustavy XIX veka v svete natsional'noi doktriny obrazovaniia // Sotsial'no-gumanitarnye znaniia. 2003. No. 1. P.35-47; Oleseiuk E. V.Sizov V. V., Kruglov Iu. G., Shu- 
find the position of E. V. Oleseyuk and his colleagues somewhat isolationist, I am inclined to identify with A. Yu. Andreev's view.

Recognizing the importance and necessity of the above-described researches for history, I would like to argue that the scholaraly perspectives of the topic lie with the social turn in the studies of university history. The deficiency of Russian historiography is that due to the traditional state centricity it interprets and studies universities as part of the state machine. However, universities are not only a driving belt of the state educational, scientific, and personnel policy, but also a set of unique people (which was especially relevant for the $19^{\text {th }}$ century), who differ from the majority of the population in terms of culture and intellect. It is what makes the human dimension of university analysis very important. On understanding this, the researchers of university history began to shift their focus from functioning of individual elements of the university system to social, anthropological, historical and cultural aspects.

Due to the interest in the revolutionary themes, Soviet historiographers did a lot of research on the student body of the $19^{\text {th }}-20^{\text {th }}$ centuries, though many of their works appeared one-sided, being focused on socio-political aspects. The early $21^{\text {st }}$ century brought about studies that viewed the student body as a broader and more complex problem. This approach is apparent in the works by A.E. Ivanov, who concentrates on the relationship among students, their daily life and rituals ${ }^{22}$.

Unlike students, the professional community of university professors has seldom been in the centre of scholarly attention.

The "social turn" of Russian historians was greatly influenced by the German researcher Trude Maurer, who passed away in April 2017. Her monograph "Hochschullehrer im Zarenreich. Ein Beitrag zur russischen Sozial- und Bildungsgeschichte" (Professors in Tsarist Russia. To the Study of Russian Social History and the History of Education) has become a very significant event in the historiography of Russian universities as social institutions ${ }^{23}$.

In this monograph, T. Maurer focuses on three aspects: the state status of professors, their university career and involvement in political processes. It should be noted that T. Maurer's work mainly draws on the previously published sources and research literature available at that time. Though she relied only on the documents from eleven RSHA funds, two SARF funds, one IAE fund and one fund of the Pushkin House Manuscript Department, she managed to give an insight into the life of the pre-revolutionary professorial community, exactly identifying their place in the Russian society as "between bureaucracy and intelligentsia."

In fact, it was T. Maurer who suggested that Russian researchers should shift the emphasis from "university regulations" to studying people and their activities. In her famous collection of articles "The Barometers" or "Beacons" of Society?: Selected Articles on the Social History of Russian and German Universities", T. Maurer states that, as a researcher,

lus A. A. Byl li "russkii put" razvitiia universitetov? // Sotsial'no-gumanitarnye znaniia. 2009. No. 3. P. 145158; Dines V.A. Eshche raz o natsional'nykh modeliakh obrazovaniia i o novom prochtenii istoricheskikh tekstov // Sotsial'no-gumanitarnye znaniia. 2009. No. 6. P.305-320.

22 Ivanov A. E.: 1) Studencheskaia korporatsiia Rossii kontsa XIX — nachala XX veka: opyt kul'turnoi i politicheskoi samoorganizatsii. M., 2004; 2) Mir rossiiskogo studenchestva. Konets XIX — nachalo XX veka. M., 2010.

${ }^{23}$ Maurer T. Hochschullehrer im Zarenreich. Ein Beitrag zur russischen Sozial- und Bildungsgeschichte. Köln; Weimar; Wien, 1998. 
she perceives universities as "communities shaped by its two constituent groups: professors and students" 24 .

Many Russian-speaking historians accepted this approach of paying more attention to social aspects of higher education, which enabled a Ukrainian researcher S. I. Posokhov to identify the transition from socio-political to cultural history as a trend of modern historiography of university history ${ }^{25}$.

The first Russian historiographer who emphasized the need to create a collective biography of professors was V.S. Kazakova ${ }^{26}$. She was followed by E. A. Vishlenkova and her colleagues, who published the monograph "Russian Professoriate. Creators of Statuses and Senses", where they emphasize that they were attracted by a different aspect: "how university people understood themselves, what language they used to describe themselves, how they created their community and what they used for it" 27 . Another interesting experience was a collective biography of professors of a previously understudied University of Warsaw by a Ukrainian researcher A. Yu. Bazhenova, published in Poland first in Russian, and later in Polish ${ }^{28}$.

Among the most prospective Russian studies of the university's past is the search for new information opportunities of the sources on the history of universities and university corporations $^{29}$.

Intra-corporate relations in various universities are now studied fruitfully by A. V. Antoshchenko, L.A. Bushueva (Sazonova), M. V. Gribovskiy, A. N. Dmitriev, and E. A. Rostovtsev ${ }^{30}$.

${ }^{24}$ Maurer T. "Barometry" ili "maiaki" obshchestva? Izbrannye stat'i po sotsial'noi istorii russkikh i nemetskikh universitetov. M., 2015. P. 30.

${ }_{25}$ Posokhov S. I. Obrazy universytetiv Rosiǐs'koï imperiï druhoï polovyny XIX - pochatku XX st. v publitsystytsi ta istoriohrafii. Kharkiv, 2006. P. 358.

${ }^{26}$ Kazakova V.S. Kollektivnaia biografiia professury - novyi put'v sotsial'noi istorii russkikh universitetov // Klio. Zhurnal dlia uchenykh. 2001. No. 1 (13). P.254-258. - Let us note that the idea of a collective biography fit into the world research agenda; a few years earlier a similar question was posed by Canadian researchers; see: Bruneau W. Toward a New Collective Biography. The University of British Columbia Professoriate, 1915-1945 // Canadian Journal of Education / Revue canadienne de léducation. 1994. Vol.19, no. 1. P. 65-79.

27 Soslovie russkikh professorov. Sozdateli statusov i smyslov. M., 2013.

28 Bazhenova A.Iu.: 1) Istoriki Imperatorskogo Varshavskogo universiteta 1869-1915: prosveshchenie, nauka, politika. Liublin, 2014; 2) Historycy Cesarskiego Uniwersytetu Warszawskiego 1869-1915: nauka i polityka. Lublin, 2016.

29 See: Zheliaskov S., Levchenko V. Metricheskie knigi Aleksandro-Nevskoi tserkvi Imperatorskogo Novorossiiskogo universiteta kak istochnik biograficheskikh issledovanii ego professorsko-prepodavatel'skogo sostava // IUgo-Zapad. Odessika. Istoriko-kraevedcheskii nauchnyi al'manakh. Iss. 11. Odessa, 2011. P.22-34; Zharova E. Iu. Izdavaemye universitetami "Obozreniia prepodavaniia nauk" kak istoricheskii istochnik po istorii vysshego obrazovaniia v dorevoliutsionnoi Rossii // Istoricheskoe obozrenie. 2013. No. 14. P. 68-73; Kiseleva Iu.A. Tsennosti universitetskoi kul'tury skvoz' prizmu chuvstv (Po vospominaniiam vospitannikov i professorov Imperatorskogo Char'kovskogo universiteta) // Dialog so vremenem. Al'manakh intellektual'noi istorii. 2017. No. 60. P. 111-127.

30 Antoshchenko A. V. Istoriia odnoi professorskoi otstavki // Kazus. Individual'noe i unikal'noe v istorii. 2002. No. 4. P. 234-274; Sazonova L. A. Korporativnye otnosheniia professorov Kazanskogo universiteta. Vtoraia polovina XIX veka // Obrazovanie i prosveshchenie v gubernskoi Kazani. Iss. 2. Kazan', 2009. P. 169175; Bushueva L. A. Professorskaia korporatsiia Kazani v epokhu peremen: mezhlichnostnye kommunikatsii universitetskikh liudei (nachalo XX veka) // Dialog so vremenem. Al'manakh intellektual'noi istorii. 2011. No. 36. P. 248-266; Rostovtsev E. A. Kazus professora fon Lista (epizod iz universitetskoi istorii perioda Pervoi mirovoi voiny) // Uroki istorii - uroki istorika. Sb. statei k 80-letiiu Iu.D. Margolisa (1930-1996). SPb., 2012. P.308-315; Gribovskiy M. V. Fenomen privat-dotsentury v rossiiskikh universitetakh kontsa XIX - 
A special case of intra-corporate relationship analysis is university conflictology, which reconstructs the relationship within the academic staff through the analysis of conflict situations ${ }^{31}$.

Another interesting topic is academic mobility in the pre-revolutionary Russia. M. V.Loskutova, a researcher from St. Petersburg, in her case studies of several faculties of Imperial St. Petersburg and Kazan Universities covered 330 biographies of professors, lecturers, private docents, laboratory assistants, and office curators who served in the above-mentioned universities in the 1850s and 1890s. As she notes, "the analysis of territorial mobility of Russian scientists and professors in the 19th century can become the first step towards understanding the role of academic institutions and professoriate in the functioning of the Russian Empire as a single political and cultural space"32. The study of academic mobility is closely connected with the study of scientific ties in the late $19^{\text {th }}-$ early $20^{\text {th }}$ centuries $^{33}$.

Another promising direction is the dissertation ethics in Russian universities at the turn of $20^{\text {th }}$ century. Though the problem has already been studied extensively, some of its aspects have not been sufficiently investigated yet. It is interesting to note how the focus of research shifted from the functional analysis of the system of academic degrees in the $1990 \mathrm{~s}-2000 \mathrm{~s}^{34}$ to the socio-anthropological analysis of the dissertational culture in the 2010s, which is mostly apparent in the works by N. N. Alevras, V.P. Korzun, S. I. Posokhov, T. Sanders ${ }^{35}$.

nachala XX v. // Vestnik of the Moscow State Regional University. Ser. History and Political Science. 2012. No. 2. P. 103-108; Dmitriev A. N. Statusy znaniia (o sotsial'nykh markerakh evoliutsii rossiiskogo universiteta pervoi treti XX veka) // Novoe literaturnoe obozrenie. 2013. No. 4 (122). URL: http://magazines.russ.ru/ nlo/2013/122/16d.html (accessed 06.06.2018).

${ }^{31}$ Ermichev A.A.O tom, kak possorilis' dva uchenykh muzha. Ocherk istorii nravov universitetskoi professury v Rossii nachala XX v. // Voprosy filosofii. 2003. No. 5. P. 124-134; Sveshnikov A. V. "Vot Vam istoriia nashei istorii". K probleme tipologii nauchnykh skandalov vtoroi poloviny XIX - nachala XX v. // Mir istorika. Iss. 1. Omsk, 2005. P. 256-260; Vishlenkova E. A. Pamiat' o konfliktakh: osobennosti arkhiva Kazanskogo imperatorskogo universiteta // Ekho vekov. 2008. No. 2. P.248-257; Beliaeva O. M. Akademicheskoe soobshchestvo Peterburgskogo universiteta v rektorstvo E. D. Grimma. Konflikty v professorskoi srede // Dialog so vremenem. Al'manakh intellektual'noi istorii. 2011. No. 34. P. 215-235; Nikiforov Iu.S. Kommunikativnaia kul'tura rossiiskikh istorikov kontsa XIX — nachala XX v. Vzaimodeistvie i konflikty v universitetskoi srede // Ibid. 2014. No. 48. P. 138-164.

${ }^{32}$ Loskutova M. V. Geograficheskaia mobil'nost' professorov i prepodavatelei rossiiskikh universitetov vtoroi poloviny XIX v.: postanovka problemy i predvaritel'nye rezul'taty issledovanii // "Byt' russkim po dukhu i evropeitsem po obrazovaniiu": Universitety Rossiiskoi imperii v obrazovatel'nom prostranstve Tsentral'noi i Vostochnoi Evropy XVIII-XX v. M., 2009, p. 187.

${ }^{33}$ See: Fuks E. Vliianie voiny na mezhdunarodnye nauchnye sviazi // Nauka, tekhnika i obshchestvo Rossii i Germanii vo vremia Pervoi mirovoi voiny. SPb., 2007. P. 94-113.

${ }^{34}$ Mazalova E. A. Uchenye stepeni i podgotovka prepodavatel'skikh kadrov v Sankt-Peterburgskom universitete v XIX-XX vv. // Istoriia uchenykh stepenei v Rossii i Zapadnoi Evrope (XII-XX vv.): materialy nauchnoi konferentsii. M., 1998. P. 43-46; Chartanovich M. F. Prisvoenie uchenykh stepenei v Rossii vo vtoroi polovine XIX v. // Ibid. P.67-73; Iakushev A. N., Kaznacheev D. A. Problemy zakonodatel'stva v sfere proizvodstva v uchenye stepeni v Rossiiskoi imperii // Pravo i obrazovanie. 2006. No. 3. P.162-177; Iakushev A. N., Kononova S. Prisuzhdenie uchenykh stepenei v universitetakh Rossiiskoi imperii (statisticheskii analiz) // Vysshee obrazovanie v Rossii. 2006. No. 3. P.147-150; Sharshunov V. A. Istoriia sozdaniia gosudarstvennoi sistemy attestatsii uchenykh i pedagogov v Rossiiskoi imperii // Problemy upravleniia. 2007. No. 3 (24). P. 74-91.

35 Posokhov S. I. "Schitaiu dlia sebia neprilichnym...": eticheskie aspekty protsessa zashchity dissertatsii v universitetakh Rossiiskoi imperii XIX — nachala XX v. // Kharkivs'kii istoriografichnii zbirnik. Iss. 11. Kharkiv, 2012. P. 131-153; Sanders T. Tretii opponent: zashchita dissertatsii i obshchestvennyi profil' akademicheskoi istorii v Rossiiskoi imperii // Istoricheskaia kul'tura imperatorskoi Rossii: formirovanie predstav- 
Unlike the thoroughly studied topic of student leisure (e.g. works by L. A. Bushueva), professorial daily life and leisure do not seem to be fully investigated ${ }^{36}$. Another understudied, but promising direction is the study of the symbolic spheres in the pre-revolutionary university ${ }^{37}$.

A research team led by A. V. Kupriyanov and M. R. Demin from St. Petersburg branch of Higher School of Economics has been investigating the national pre-revolutionary universities with the use of big data processing, which allows generating data on specified parameters. In particular, the team has studied the personnel dynamics of Russian Imperial universities and developed approaches to studying the academic mobility of pre-revolutionary professors with the use of big data analytics ${ }^{38}$.

There is much potential in studying universities within the context of urban space. This approach stems from the fact that the university as a product of urban culture has always been closely associated with city institutions and urban communities. The professorial community has always greatly affected urban life. The relationship between the university and the city can be intepreted as a mutual exchange of opportunities and resources. This approach was employed by historians from Russia, Germany and Estonia in their book on St. Petersburg, Moscow, Kazan and Yuryev universities of the early 20th century. Later, a Kharkov researcher S.I. Posokhov used it in his case study of Moscow, Kazan, and Kharkov universities of the middle of $18^{\text {th }}-$ middle $19^{\text {th }}$ centuries $^{39}$. There is also a special study on the history of Kazan University written partly from the cultural-urban positions ${ }^{40}$. Such studies have a benefit of giving a picture of the city as of a cultural, rather than socio-economical phenomenon.

Finally, it should be mentioned that by now there are theses defended on the history of pre-revolutionary professoriate of four of the eleven universities: Imperial Tomsk Uni-

lenii o proshlom. M., 2012. P. 161-192; Alevras N. N. Dissertatsionnaia kul'tura rossiiskikh istorikov: vzgliad na problemu shest' let spustia // Dissertatsiia po istorii v kontekste rossiiskoi nauchnoi kul'tury XIX - serediny XX vv.: opyt i perspektivy izucheniia. Cheliabinsk. 2016. P.4-18; Korzun V.P. O sootnoshenii poniatii dissertatsionnaia kul'tura i professorskaia kul'tura: Definitsii kak issledovatel'skaia optsiia: dis. po istorii $\mathrm{v}$ kontekste rossiiskoi nauchnoi kul'tury XIX — serediny XX vv.: opyt i perspektivy izucheniia. Cheliabinsk, 2016. P. 19-25.

36 Bushueva L. A. Dosug universitetskikh professorov Kazani kontsa XIX - nachala XX v. // Izvestiia Samarskogo nauchnogo tsentra Rossiiskoi akademii nauk. 2011. Vol. 13, no. 3. P. 80-83.

37 Vishlenkova E. A. Universitetskie ritualy (na materialakh Imperatorskogo Kazanskogo universiteta) // Kharkivs'kii istoriografichnii zbirnik. Iss. 7. Kharkiv, 2004. P. 4-14; Parfinenko A. Iu., Posokhov S. I. Starye i novye simvoly universitetov (na materialakh Xar'kovskogo universiteta vtoroi poloviny XIX - pervoi poloviny XX vekov) // Epokha. Kul'tury. Liudi (istoriia povsednevnosti i kul'turnaia istoriia Germanii i Sovetskogo Soiuza. 1920-1950-e gody): materialy Mezhdunarodnoi nauchnoi konferentsii. Sb. dokladov. Khar'kov, 2004. P. 236-248.

38 Ivanova E.: 1) Chto mozhet dat' edinaia baza dannykh po professure dorevoliutsionnoi Rossii issledovateliam akademicheskoi mobil'nosti? // Sotsiologiia v deistvii - 2015: izbrannye materialy VII sotsiologicheskoi Mezhvuzovskoi konferentsii studentov i aspirantov. SPb., 2015. P. 131-141;2) Popytka postroeniia kauzal'noi modeli kadrovoi dinamiki professorsko-prepodavatel'skogo sostava universitetov dorevoliutsionnoi Rossii // Ibid. P. 118-136; Kostina T. V., Kouprianov A. V. Growth or stagnation? Historical dynamics of the growth patterns of Dorpat University (1803-1884) // Vestnik of Saint- Petersburg University. History. 2016, iss. 3. P.31-45; Kupriianov A. V. Ot prosopografii universitetskoi professury do tsifrovogo sleda filosofskogo parokhoda: "Srednie dannye" i formalnye podkhody v istorii nauki // Topos. 2017. No. 1-2. P. 111-137.

39 Posokhov S. I. Universitet i gorod v Rossiiskoi imperii (vtoraia polovina XVIII - pervaia polovina XIX vv.). Khar'kov, 2014.

40 Vishlenkova E. A., Malysheva S.Iu. Sal'nikova A. A. Terra Universitatis: dva veka universitetskoi kul'tury v Kazani. Kazan', 2005. 
versity (S. A. Nekrylov, 1999), Imperial Moscow University (N. N. Niks, 2004), Imperial Kazan University (L. A. Sazonova, 2009) and Imperial St. Petersburg University (E. A. Rostovtsev, 2017). Their foci are quite different. S. A. Nekrylov studies the academic staff of the oldest university in the Asian part of Russia, including its social characteristics as well as educational, scientific, and public activities ${ }^{41}$. L. A. Sazonova concentrates on the history of everyday life of Kazan professors, social characteristics of the professorial corporation and corporate relations ${ }^{42}$. N. N. Niks investigates the Moscow professoriate on the whole, with an emphasis on the socio-cultural aspect ${ }^{43}$. E. A. Rostovtsev examines student and professorial corporations of Imperial St. Petersburg University, without addressing the research activities of professors ${ }^{44}$.

The main object of his analysis is the university corporation, which he understands as a body of professors, assistants and students. This approach appears to be innovative for Russian historiography, which traditionally studies professorial and student communities separately. The emphasis of the work is laid on the problem of university autonomy. Although the topic has already been looked on in historical and philosophical studies from different angles, E. A. Rostovtsev comes to an important conclusion that the actual autonomy of universities was incomparably more formal, being stipulated by the University Statute of 1884 and subsequent normative acts. Of great value in this work is the differentiation of faculties based on the specificity of academic groups depending on specialty or a branch of science. Thus, the professors of the Faculty of Physics and Mathematics are defined as those who made a particularly significant contribution to science; the academic staff of the Faculty of Law is distinguished by their greater involvement in social and political processes, and the professoriate of the Faculty of the Eastern Studies as having the most stable composition among other faculties. E. A. Rostovtsev concludes that there are several corporate structures within the university community. Though his thesis represents a case study of only one university, Rostovtsev manages to give a detailed picture of university life in Russia at the turn of the $20^{\text {th }}$ century, which opens up a path for further studies of university history.

As far as foreign historiography of the topic is concerned, it should be noted that the formalised approach within which the research is limited exclusively by state borders is less desirable.

First, there is a separate group that includes works by Polish, Ukrainian, and Estonian researchers since some universities of the former Russian Empire are located in these countries. With a few exceptions, historians from these countries focus on the past of "their" universities (Warsaw, St. Vladimir, Novorossiysk, Kharkov, and Yuryev), with rare research on the universities of the Russian Empire as a whole. Within the above-stated group, Ukrainian research framework was the closest to that of Russian historiography, at least until recently. Most of Ukrainian works were written in Russian. A number of them

${ }^{41}$ Nekrylov S.A.Professorsko-prepodavatel'skii korpus Imperatorskogo Tomskogo universiteta (1888 - fevral' 1917 gg.): diss. ... kand. ist. nauk. Tomsk, 1999.

42 Sazonova L. A. Povsednevnost' universitetskogo professora Kazani 1863-1917 gg.: diss. ... kand. ist. nauk. Kazan', 2009.

${ }^{43}$ Niks N. N. Moskovskaia professura vtoroi poloviny XIX - nachala XX v. Sotsiokul'turnyi aspekt: diss. ... kand. ist. nauk. M., 2004.

${ }_{44}$ Rostovtsev E.A.Sankt-Peterburgskii universitet v kontekste sotsial'no-politicheskoi istorii Rossii (1884-1917): diss. ... dokt. ist. nauk. In 2 vol. SPb., 2017. 
have already been described in this paper (see the works by A. Ya. Bazhenova ${ }^{45}$, M. A. Balyshev, S. A.Zhelyaskov, Yu.A. Kiseleva, V. V. Levchenko, S. I. Posokhov and others).

Estonian and, in particular, Polish historiographies are rather indifferent to the history of "Russian universities". For quite long, Polish historiographers of higher education treated the imperial period of its development as secondary. Only since the 1980s, Polish researchers have begun to gradually and then systematically include the history of Imperial University of Warsaw in the paradigm of their research on history of science and higher education in Poland ${ }^{46}$.

Although contemporary Polish historiography acts on a well-founded assumption that the main mission of the University of Warsaw was the Russification in the western part of the Empire, an increasing number of researchers choose to carry out a comprehensive and multifaceted investigation of the university activities in the University of Warsaw at the time when it was not truly Polish. In this regard, I should mention the works by J.Schiller-Walicka ${ }^{47}$, particularly her monograph Universitas Rossica. Koncepcja rosyjskiego uniwersytetu 1863-1917 (Universitas Rossica. The Concept of Russian University in 1863-1917 $)^{48}$, where she goes beyond the Polish set of problems to discuss how the idea invested in the University by the Russian government related to the realities of the second half of the $19^{\text {th }}-$ early $20^{\text {th }}$ centuries.

In addition, it should be pointed out that by far the majority of Polish works on university history focus on the development of certain branches of university science, with much less attention paid to the professoriate as a social group.

The $200^{\text {th }}$ anniversary of the University of Warsaw caused the intensification of research, which brought about many publications, including biographical dictionaries of professors. Of particular interest among them is a substantial scholarly monograph Dzieje Uniwersytetu Warszawskiego. 1816-1915 (History of the University of Warsaw, 1816-1915 $)^{49}$, which was not a jubilee informational and advertising edition as it was a serious summarizing work on pre-revolutionary university history, with three chapters devoted to the period under study. Two of these chapters describe scientific development and the student body, yet the most interesting is the third one - "Cesarski uniwersytet Warszawski: Między edukacją a polityką. 1869-1917” (Imperial University of Warsaw: Between Education and Politics, 1869-1917). In spite of an expected emphasis on the relationship between the official Russian university and the Polish component and attempts by some professors to gain the right to teach in the Polish language, the authors create a complex and ambiguous picture of the university life in the second half of the $19^{\text {th }}$ and early $20^{\text {th }}$ centuries, thus demonstrating that contemporary Polish historians have managed to avoid stereotypically negative assessments of the past.

45 Anna Bazhenova can be called a Ukrainian-Polish researcher; her main research interest is connected with the analysis of the professional community of historians of the Warsaw University.

${ }^{46}$ Dzieje Uniwersytetu Warszawskiego 1807-1915 / ed. by S. Kieniewicz. Warszawa, 1981; Historia nauki polskiej / ed. by B. Suchodolski. T. IV. 1863-1918. Cz. III. Wrocław, 1987.

47 Schiller J.: 1) Profesorowie Cesarskiego Uniwersytetu Warszawskiego wobec wydarzeń rewolucji 1905 roku // Rozprawy z Dziejow Oswiaty. 2008. T.XVII (XLII). S. 75-97; 2) Aleksandr Lwowicz Błok (1852-1909) - portret niespełnionego człowieka i uczonego // Kwartalnik Historii Nauki i Techniki. 2009. No. 1. S.11-33; Shiller-Valicka I. Proekty reformy rossijskih universitetov konca XIX - nachala XX veka // Istoriya i istoricheskaya pamyat'. 2013. No. 7-8. P. 191-207.

48 Schiller J. Universitas rossica. Koncepcja rosyjskiego uniwersytetu 1863-1917. Warszawa, 2008. $709 \mathrm{~s}$.

49 Dzieje Uniwersytetu Warszawskiego. 1816-1915 / ed. by prof. Wojciech Tygielski. Warszawa, 2016. 
Modern Estonian historians of university history are Lea Leppik and Sirje Tamul, to name just a few. L. Leppik's areas of research interest include social mobility of professors of the Dorpat (Yuryev) University ${ }^{50}$, while S. Tamul focuses more on the student body of the University of Yuryev, university charity, the influence of WWI on the university in the Baltic region ${ }^{51}$.

Unlike Russian, the so-called "western" historiography was not so discrete by nature in the $20^{\text {th }}$ century and remained almost the same in the "post-Soviet" stage.

As for narrowly specialized research, the internal development of Russian universities received little, if any, attention in Western historiography until present. In most cases, Russian universities were studied as part of the socio-political history of Imperial Russia. According to St. Petersburg historiographers, Western researchers treat this topic as secondary for the university history of the West, which is why Russian universities are more interesting for specialists in the history of Russia rather than historians of education ${ }^{52}$.

Western historiography of the 1990s - 2010s retained its traditional interest in the relationship between the university (represented by the scholarly community and the student body) and Russian society ${ }^{53}$. The first chapter of the monograph Builders and Deserters: Students, State and Community in Leningrad, 1917-1941 by P. Konecny focuses on the pre-revolutionary period and describes the daily life of the St. Petersburg students and their relationships with professors.

The book Civil Society and Academic Debate in Russia. 1905-1914 by D. Wartenweiler is an interesting attempt to combine the intellectual and social history of late Imperial Russia. In his case study of two largest universities - St. Petersburg and Moscow - the author explores how liberal university professors participated in the creation of civil society in Russia in the early $20^{\text {th }}$ century, or, more precisely, the efforts of the academic community to translate the ideas of civil society into practice through educational projects. D. Wartenweiler acts out on the assumption that liberal professors pursued two, often contradictory, goals: as professionals - to preserve the university as a center of pure science, and as citizens - to promote the independence of subjects from a monarchical state ${ }^{54}$.

The book aroused much interest among specialists as can be understood from a series of positive reviews ${ }^{55}$.

${ }^{50}$ Leppik L.: 1) Tartu Ülikooli teenistujate sotsiaalne mobiilsus 1802-1918. Tartu, 2006; 2) Social Mobility and Career Patterns of Estonian Intellectuals in the Russian Empire // Historical Social Research. 2008. No. 33 (2). P. 42-62; 3) Tartu ülikool ja meditsiiniteenuste turg 19 Sajandil // Eesti Tervisekaitse seltsi 54. konverentsi ettekannete kogumik. Tallinn, 2008. L. 28-29; 4) Kalefaktoripojast professoriks. Tartu ülikooli teenistujate sotsiaalne mobiilsus 1802-1918. Tartu, 2011.

51 Tamul S.: 1) Über die Studentenschaft der russifizierten Tartuer Universität (1883-1918) // Universitätsgeschichte in Osteuropa, Stuttgart, 2001. S.102-111; 2) Donatsioonid Tartu ülikoolile aastatel 1802-1918 // Ajalooline Ajakiri. 2002. S. 177-192; 3) Die Bedeutung des Krieges für die Universität Jur'ev: Schließungsabsichten und Evakuierungsmaßnahmen (1915-1918) // Kollegen - Kommilitonen - Kämpfer. Europäische Universitäten im Ersten Weltkrieg / Hrsg. von T. Maurer. Stuttgart, 2006. S. 223-238.

52 Rostovtsev E. A., Barinov D. A., Krivonozhenko A. V., Sidorchuk I. V. Akademicheskaia korporatsiia stolichnogo universiteta $\mathrm{v}$ fokuse istoriografii // Klio. 2012. No. 7. P. 55.

${ }^{53}$ Morrissey S. K. Heralds of Revolution. Russian Students and the Mythologies of Radicalism. Oxford; New York, 1998; Konecny P. Builders and Deserters: Students, State and Community in Leningrad, 1917-1941. Montreal, 1999.

54 Wartenweiler D. Civil Society and Academic Debate in Russia. 1905-1914. Oxford, 1999. XII, 252 p.

55 Stockdale M. K. Civil Society and Academic Debate in Russia, 1905-1914 by David Wartenweiler [Review] // Russian History. 2000. Vol.27, no. 3. P.348-350; Hickey M. C. Civil Society and Academic Debate in Russia, 1905-1914 by David Wartenweiler [Review] // History of Education Quarterly. 2000. Vol.40, 
A qualitatively new approach to the study of the university history of Russia in European historiography is associated with T. Maurer and her works, which have already been discussed above.

West European and American researchers take a detached view of the past of Russian universities as they do not write the story of "their" Alma Mater. There is no doubt that such a view is extremely important for the formation of an objective historical evaluation.

Thus, the conducted analysis has shown that contemporary Russian historiography of the pre-revolutionary universities in Russia is developing very rapidly seeking new approaches to studying the past. It is supplemented by foreign researches, particularly in those countries where former Russian Imperial Universities are located. In this respect Ukrainian researchers (namely, from Kharkiv) and, to a lesser extent, Polish and Estonian, with their typically indifferent attitude to the past of "Russian universities" are most productive.

The recent decades have been marked by a growing demand for social history in Russian scholarship. Following European and American practices, Russian historians widely employ social approaches in their research, which brings about increased cognitive abilities of history. Now researchers are eager to analyze various social groups, looking at the past from multiple angles. Being centred on people, this approach turns out to be very effective in the studies of higher education history.

Since 2018, Tomsk, St. Petersburg and Moscow historians have been implementing the project "Collective Biography of Professors of Russian Universities in the Mirror of Social History (the second half of the $18^{\text {th }}-$ early $20^{\text {th }}$ centuries) supported by the Russian Scientific Foundation, which aims at filling the historical gaps by creating a wide portrayal of social history of Russian universities for the entire pre-revolutionary period.

\section{References}

Alevras N. N. Dissertatsionnaia kul'tura rossiiskikh istorikov: vzgliad na problemu shest' let spustia. Diss. po istorii v kontekste rossiiskoi nauchnoi kul'tury XIX - serediny XX v.: opyt i perspektivy izucheniia. Cheliabinsk, Chelyabinsk State University, 2016, pp. 4-18. (In Russian)

Andreev A. Yu. "Ideia universiteta" v Rossii (XVIII - nachalo XX v.). "Byt' russkim po dukhu i evropeitsem po obrazovaniiu”. Universitety Rossiiskoi imperii v obrazovatel'nom prostranstve Tsentral'noi $i$ Vostochnoi Evropy XVIII - nachala XX v. Ed. by A. Y. Andreev. Moscow, ROSSPEN, 2009, pp. 9-31 (In Russian)

Andreev A. Iu. Lektsii po istorii Moskovskogo universiteta. 1755-1855. Moscow, Moscow State University Press, 2001, 240 p. (In Russian)

Andreev A.Iu. "Natsional'naia model"” universitetskogo obrazovaniia: vozniknovenie i razvitie. Vysshee obrazovanie v Rossii. 2005, no. 1, pp. 156-169; no. 2, pp. 110-119 (In Russian)

Andreev A.Iu. O "novom prochtenii" istorii rossiiskikh universitetov. Vysshee obrazovanie v Rossii, 2009, no. 3, pp. 156-169. (In Russian)

Andreev A.Iu. Rossiiskie universitety XVIII - pervoi poloviny XIX veka v kontekste universitetskoi istorii Evropy. Moscow, Znak, 2009, 640 p. (In Russian)

Andreev A. Iu. Sushchestvoval li "russkii put” razvitiia universitetov? Vysshee obrazovanie v Rossii, 2008, no. 7, pp. 113-119. (In Russian)

Andreev A.Iu., Posokhov S. I. Universitet v Rossiiskoi Imperii XVIII - pervoi poloviny XIX veka. Moscow, ROSSPEN, 2012, 671 p. (In Russian)

no. 4. P. 483-485; Kassow S. D. Civil Society and Academic Debate in Russia, 1905-1914 by David Wartenweiler [Review] // The American Historical Review. 2001. Vol. 106, no. 2. P. 683-684; Balzer H. Civil Society and Academic Debate in Russia, 1905-1914 by David Wartenweiler [Review] // The Russian Review. 2004. Vol. 63, no. 1, pp. 166-167. 
Antoshchenko A. V. Istoriia odnoi professorskoi otstavki. Kazus. Individual'noe i unikal'noe v istorii, 2002, no. 4, pp. 234-274. (In Russian)

Antoshchenko A. V.Professor imperatorskogo Moskovskogo universiteta Pavel Gavrilovich Vinogradov (ocherki zhizni i deiatel'nosti). Moscow, [S. n.], 2015, 336 p. (In Russian)

Avrus A. I. Istoriia rossiiskikh universitetov. Ocherki. Moscow, [S. n.], 2001, 85 p. (In Russian)

Balyshev M. A. Professor istorii Mikhail Vasil'evich Klochkov. Dokumental'no-biograficheskii ocherk. UNIVERSITATES. Nauka i prosveshchenie (Khar'kov), 2005, no. 2, pp. 18-29. (In Russian)

Balzer H. Civil Society and Academic Debate in Russia, 1905-1914 by David Wartenweiler [Review]. The Russian Review, 2004, vol. 63, no. 1, pp. 166-167.

Bażenowa Anna. Historycy Cesarskiego Uniwersytetu Warszawskiego 1869-1915: nauka i polityka. Lublin, Instytut Europy Środkowo-Wschodniej, 2016, 418 s.

Bazhenova A. Iu. Istoriki Imperatorskogo Varshavskogo universiteta 1869-1915: prosveshchenie, nauka, politika. Liublin, Instytut Europy Środkowo-Wschodniej, 2014, 408 p. (In Russian)

Beliaeva O.M. Akademicheskoe soobshchestvo Peterburgskogo universiteta v rektorstvo E. D. Grimma. Konflikty v professorskoi srede. Dialog so vremenem. Almanakh intellektual'noi istorii, 2011, no. 34, pp. 215-235. (In Russian)

Bruneau W. Toward a New Collective Biography: the University of British Columbia Professoriate, 19151945. Canadian Journal of Education / Revue canadienne de l'éducation, 1994, vol. 19, no. 1, pp. 65-79.

Bushueva L. A. Dosug universitetskikh professorov Kazani kontsa XIX - nachala XX v. Izvestiia Samarskogo nauchnogo tsentra Rossiiskoi akademii nauk, 2011, vol. 13, no. 3, pp. 80-83. (In Russian)

Bushueva L.A.Professorskaia korporatsiia Kazani v epokhu peremen: mezhlichnostnye kommunikatsii universitetskikh liudei (nachalo XX veka). Dialog so vremenem. Al'manakh intellektual'noi istorii, 2011, no. 36, pp. 248-266 (In Russian)

Chartanovich M. F. Prisvoenie uchenykh stepenei v Rossii vo vtoroi polovine XIX v. Istoriia uchenykh stepenei $v$ Rossii i Zapadnoi Evrope (XII-XX vv.). Materialy nauchnoi konferentsii. Moscow, Russian State University for the Humanities Press, 1998, pp. 67-73. (In Russian)

Cherkaz'ianova I.V.Aleksandr Nikolaevich Shvarts: okruzhenie, vospriiatie, otsenki. Kharkivs'kii istoriografichnii zbirnik. Iss. 7. Kharkiv, N. V. Karazin Kharkiv National University Press, 2004, pp. 8494. (In Russian)

Dines V. A. Eshche raz o natsional'nykh modeliakh obrazovaniia i o novom prochtenii istoricheskikh tekstov. Sotsial'no-gumanitarnye znaniia, 2009, no. 6, pp. 305-320 (In Russian)

Dines V. A., Oleseiuk E. V., Shulus A. A. Ocherki po istorii i teorii otechestvennoi vysshei shkoly. Saratov, Saratov State Social and Economic University Press, 2002, 124 p. (In Russian)

Dosekin E. S. Evgenii Nikolaevich Trubetskoi - obshchestvennyi i politicheskii deiatel'. Samara, Samara State Institute of Culture Press, 2014, 116 p. (In Russian)

Dvornichenko A. Iu. Kafedra istorii Rossii s drevneishikh vremen do nachala XX veka. Institut istorii Sankt-Peterburgskogo gosudarstvennogo universiteta segodnia. K 80-letiiu osnovaniia Istoricheskogo fakul'teta $L G U-S P b G U$.St. Petersburg, Institut istorii Sankt-Peterburgskogo gosudarstvennogo universiteta, 2014, pp. 29-37. (In Russian)

Dvornichenko A.Iu., Rostovtsev E. A., Barinov D. A. The department of Russian history at St. Petersburg university (1821-1917): A group portrait. Vestnik of Saint-Petersburg University. History, 2016, iss. 3, pp. $46-56$.

Eremina T. I. O poriadke deloproizvodstva $\mathrm{v}$ universitetskikh sudakh $\mathrm{v}$ otnoshenie studentov (na primere Sankt-Peterburgskogo i Kazanskogo universitetov). Istoriko-pravovye problemy: novyi rakurs. Iss. 9-1. Kursk, Kursk State University Press, 2014, pp. 57-63. (In Russian)

Ermichev A. A. O tom, kak possorilis' dva uchenykh muzha. Ocherk istorii nravov universitetskoi professury v Rossii nachala XX v. Voprosy filosofii, 2003, no. 5, pp. 124-134. (In Russian)

Fominykh S. F., Nekrylov S. A., Gribovskiy M. V., Mendrina G. I., Vengerovskii A. I., Novitskii V. V. Professora meditsinskogo fakul'teta Imperatorskogo (gosudarstvennogo) Tomskogo universiteta - Tomskogo meditsinskogo instituta - Sibirskogo gosudarstvennogo meditsinskogo universiteta (1878-2003). Biograficheskii slovar. Vol. 1-2. Tomsk, Tomsk State University Press, 2013, 488, 574 p. (In Russian)

Frolov E.D. Nemetskii professor v russkom universitete: Ernst Romanovich fon Shtern (1859-1924). Problemy sotsial'noi istorii i kul'tury srednikh vekov i rannego novogo vremeni, 2001, no. 3, pp. 29-52. (In Russian)

Fuks E. Vliianie voiny na mezhdunarodnye nauchnye sviazi. Nauka, tekhnika i obshchestvo Rossii i Germanii vo vremia Pervoi mirovoi voiny. Ed. by E. I. Kolchinskii. St. Petersburg, Nestor Istoriia, 2007, pp. 94113. (In Russian) 
Golovko L.V., Il'iutchenko N.V.Professorskii distsiplinarnyi sud pri Imperatorskom Moskovskom universitete. Vestnik of Moscow University. Ser.11. Right, 2004, no. 6, pp. 94-110. (In Russian)

Gribovskiy M. V. Fenomen privat-dotsentury v rossiiskikh universitetakh kontsa XIX - nachala XX v. Vestnik of the Moscow State Regional University. Ser. History and Political Science, 2012, no. 2, pp. 103108. (In Russian)

Gurkina N. K. Istoriia obrazovaniia v Rossii (X-XX veka). Uchebnoe posobie. St. Petersburg, St. Petersburg State University of Aerospace Instrumentation Press, 2001, 64 p. (In Russian)

Gurkina N. K. Istoriia obrazovatel'nykh uchrezhdenii v Rossii (X-XX veka). Uchebnoe posobie. St. Petersburg, Poltorak, 2012, 78 p. (In Russian)

Hickey M. C. Civil Society and Academic Debate in Russia, 1905-1914 by David Wartenweiler [Review]. History of Education Quarterly, 2000, vol. 40, no. 4, pp. 483-485.

Iablokov S. A. Iuridicheskii fakul'tet Moskovskogo universiteta posle vvedeniia universitetskogo Ustava 1884 g. Vestnik of Moscow University. Ser.11. Right, 2006, no. 5, pp. 113-126. (In Russian)

Iakushev A. N., Kaznacheev D. A. Problemy zakonodatel'stva v sfere proizvodstva v uchenye stepeni v Rossiiskoi imperii. Pravo i obrazovanie, 2006, no. 3, pp. 162-177. (In Russian)

Iakushev A. N., Kononova S. Prisuzhdenie uchenykh stepenei v universitetakh Rossiiskoi imperii (statisticheskii analiz). Vysshee obrazovanie $v$ Rossii, 2006, no. 3, pp. 147-150. (In Russian)

Ivanov A.E. Mir rossiiskogo studenchestva. Konets XIX - nachalo XX veka. Moscow, Novyi khronograf, 2010, 360 p. (In Russian)

Ivanov A.E. Rossiiskoe "uchenoe soslovie" v gody "Vtoroi Otechestvennoi voiny" (Ocherk grazhdanskoi psikhologii i patrioticheskoi deiatel'nosti). Voprosy istorii estestvoznaniia i tekhniki, 1999, no. 2, pp. 108-127. (In Russian)

Ivanov A.E. Studencheskaia korporatsiia Rossii kontsa XIX - nachala XX veka: opyt kul'turnoi i politicheskoi samoorganizatsii. Moscow, Novyi khronograf, 2004, 408 p. (In Russian)

Ivanov A.E. V preddverii kadetskoi partii: Vserossiiskii soiuz deiatelei nauki i vysshei shkoly. Vlast' i nauka, uchenye i vlast': 1880-e - nachalo 1920-kh godov. Materialy Mezhdunarodnogo nauchnogo kollokviuma. St. Petersburg, St. Petersburg State University Press, 2003, pp. 202-212. (In Russian)

Ivanova E. Chto mozhet dat' edinaia baza dannykh po professure dorevoliutsionnoi Rossii issledovateliam akademicheskoi mobil'nosti? Sotsiologiia $v$ deistvii - 2015. Izbrannye materialy VII sotsiologicheskoi Mezhvuzovskoi konferentsii studentov i aspirantov. St. Petersburg, Otdel operativnoi poligrafii, National Research University "Higher School of Economics", 2015, pp. 131-141. (In Russian)

Ivanova E. Popytka postroeniia kauzal'noi modeli kadrovoi dinamiki professorsko-prepodavatel'skogo sostava universitetov dorevoliutsionnoi Rossii. Sotsiologiia $v$ deistvii - 2015. Izbrannye materialy VII sotsiologicheskoi mezhvuzovskoi konferentsii studentov i aspirantov. St. Petersburg, Otdel operativnoi poligrafii, National Research University "Higher School of Economics", 2015, pp. 118-136. (In Russian)

Kaledin N. V. Obshchestvennaia geografiia v Sankt-Peterburgskom universitete: istoki i etapy razvitiia. Vestnik of Saint-Petersburg University. History, 2015, no. 1, pp. 58-74. (In Russian)

Kassow S. D. Civil Society and Academic Debate in Russia, 1905-1914 by David Wartenweiler [Review]. The American Historical Review, 2001, vol. 106, no.2, pp. 683-684.

Kazakova V.S. Kollektivnaia biografiia professury - novyi put' v sotsial'noi istorii russkikh universitetov. Klio. Zhurnal dlia uchenykh, 2001, no. 1 (13), pp. 254-258. (In Russian)

Kiseleva Iu.A. Tsennosti universitetskoi kul'tury skvoz' prizmu chuvstv. (Po vospominaniiam vospitannikov i professorov Imperatorskogo Char'kovskogo universiteta). Dialog so vremenem. Al'manakh intellektual'noi istorii, 2017, no. 60, pp. 111-127. (In Russian)

Konecny P. Builders and Deserters: Students, State and Community in Leningrad, 1917-1941. Montreal, McGill-Queen's University Press, 1999, 358 p.

Korzun V.P.O sootnoshenii poniatii dissertatsionnaia kul'tura i professorskaia kul'tura: Definitsii kak issledovatel'skaia optsiia. Dissertatsiia po istorii v kontekste rossiiskoi nauchnoi kul'tury XIX - serediny XX v.: opyt i perspektivy izucheniia. Ed. by N. N. Alevras, N. V. Grishina. Cheliabinsk, Chelyabinsk State University Press, 2016, pp. 19-25. (In Russian)

Kostina T. V. Retsenziia: Gurkina N. K. Istoriia obrazovatel'nykh uchrezhdenii v Rossii (X-XX veka). SPb.: Poltorak, 2012 [review]. Istoricheskaia Ekspertiza, 2014, no. 1, pp. 167-170. (In Russian)

Kostina T. V., Kouprianov A. V. Growth or stagnation? Historical dynamics of the growth patterns of Dorpat University (1803-1884). Vestnik of Saint-Petersburg University. History, 2016, iss. 3, pp. 31-45

Kostitsyn V. I. Rektory Permskogo universiteta. 1916-2006. Perm', Perm' State University Press, 2006, 352 p. (In Russian)

Kozyrenko N. F. Istoriia al'gologii na kafedre botaniki biologo-pochvennogo fakul'teta. Vestnik of SaintPetersburg University. Ser. 3, 2005, iss. 2, pp. 62-70. (In Russian) 
Kruglov Iu.G., Oleseiuk E.V., Shulus A. A. Universitetskie ustavy XIX veka v svete natsional'noi doktriny obrazovaniia. Sotsial'no-gumanitarnye znaniia, 2003, no. 1, pp. 35-47. (In Russian)

Kupriianov A.V.Ot prosopografii universitetskoi professury do tsifrovogo sleda filosofskogo parokhoda: "Srednie dannye" i formal'nye podkhody v istorii nauki. Topos, 2017, no. 1-2, pp. 111-137. (In Russian)

Lapteva L. P. Istoriia rossiiskikh universitetov XVIII - nachala XX veka v noveishei otechestvennoi literature (1985-1999 gody). Rossiiskie universitety $v$ XVIII-XX vv. Sb. nauchnykh trudov. Iss. 5. Voronezh, Voronezh State University Press, 2000, pp. 4-27. (In Russian)

Leppik L. Kalefaktoripojast professoriks. Tartu ülikooli teenistujate sotsiaalne mobiilsus 1802-1918. Tartu, Aasta, 2011, 380 l.

Leppik L. Social Mobility and Career Patterns of Estonian Intellectuals in the Russian Empire. Historical Social Research, 2008, no. 33 (2), pp. 42-62.

Leppik L. Tartu ülikool ja meditsiiniteenuste turg 19 Sajandil. Eesti Tervisekaitse seltsi 54 . konverentsi ettekannete kogumik. Tallinn, Eesti Tervisekaitse Selts, 2008, 11. 28-29.

Leppik L. Tartu Ülikooli teenistujate sotsiaalne mobiilsus 1802-1918. Tartu, Ülikool, 2006, 3081.

Levshin L.V.Dekany fizicheskogo fakul'teta Moskovskogo universiteta. Moscow, Moscow State University Press, 2002, 272 p. (In Russian)

Litvin A.L. Uchenye Kazanskogo universiteta vo vremia smeny politicheskikh rezhimov. Vlast' $i$ nauka, uchenye i vlast': 1880-e - nachalo 1920-kh godov. St. Petersburg, Dmitrii Bulanin, 2003, pp. 124-132. (In Russian)

Loskutova M. V. Geograficheskaia mobil'nost' professorov i prepodavatelei rossiiskikh universitetov vtoroi poloviny XIX v.: postanovka problemy i predvaritel'nye rezul'taty issledovanii. "Byt' russkim po dukhu i evropeitsem po obrazovaniiu": Universitety Rossiiskoi imperii v obrazovatel'nom prostranstve Tsentral'noi $i$ Vostochnoi Evropy XVIII-XX v. Moscow, ROSSPEN, 2009, p. 187. (In Russian)

Markin V.L.Studenty i prepodavateli Moskovskogo universiteta $v$ obshchestvenno-politicheskoi zhizni Rossii nachala XX veka. Diss. ... kand. ist. nauk. Moscow, 2009, 213 p. (In Russian)

Maurer T. "Barometry" ili "maiaki" obshchestva? Izbrannye stat'i po sotsial'noi istorii russkikh i nemetskikh universitetov. Moscow, Politicheskaia entsiklopediia, 2015, 527 p. (In Russian)

Maurer T. Hochschullehrer im Zarenreich. Ein Beitrag zur russischen Sozial- und Bildungsgeschichte. Köln; Weimar; Wien, Böhlau, 1998, 959 S.

Mazalova E. A. Uchenye stepeni i podgotovka prepodavatel'skikh kadrov v Sankt-Peterburgskom universitete v XIX-XX vv. Istoriia uchenykh stepenei v Rossii i Zapadnoi Evrope (XII-XX vv.). Materialy nauchnoi konferentsii. Moscow, Russian State University for the Humanities Press,1998, pp. 43-46. (In Russian)

Morrissey S.K. Heralds of Revolution. Russian Students and the Mythologies of Radicalism. Oxford; New York, Oxford University Press, 1998, 304 p.

Nekrylov S. A. Professorsko-prepodavatel'skii korpus Imperatorskogo Tomskogo universiteta (1888 - fevral' 1917 gg.). Diss. ... kand. ist. nauk. Tomsk, 1999, 300 p. (In Russian)

Nikiforov Iu.S. Kommunikativnaia kul'tura rossiiskikh istorikov kontsa XIX - nachala XX v. Vzaimodeistvie i konflikty v universitetskoi srede. Dialog so vremenem. Al'manakh intellektual'noi istorii, 2014, no. 48, pp. 138-164. (In Russian)

Niks N. N. Moskovskaia professura vtoroi poloviny XIX - nachala XX v. Sotsiokul'turnyi aspekt. Diss. ... kand. ist. nauk. Moscow, 2004, 372 p. (In Russian)

Oleseiuk E. V.Sizov V. V., Kruglov Iu. G., Shulus A. A. Byl li "russkii put” razvitiia universitetov? Sotsial'nogumanitarnye znaniia, 2009, no. 3, pp. 145-158. (In Russian)

Oleseiuk E. V., Kruglov Iu.G., Dianova V. Iu., Nasonkin V. V., CHistokhvalov V. N. Rossiiskaia vysshaia shkola (ocherki istorii): uchebnoe posobie. Vol.1. Istoki i razvitie do 1917 g. Moscow, Taganka, 2005, 184 p. (In Russian)

Parfinenko A. Iu., Posokhov S. I. Starye i novye simvoly universitetov (na materialakh Xar'kovskogo universiteta vtoroi poloviny XIX - pervoi poloviny XX veka). Epokha. Kul'tury. Liudi (istoriia povsednevnosti i kul'turnaia istoriia Germanii i Sovetskogo Soiuza. 1920-1950-e gody). Materialy Mezhdunarodnoi nauchnoi konferentsii. Sbornik dokladov. Khar'kov, Vostochno-regional'nyi tsentr gumanitarno-obrazovatel'nyy initsiativ, 2004, pp. 236-248. (In Russian)

Posokhov S. I. Obrazy universytetiv Rosǐ̌s'koï imperiï druhoï polovyny XIX - pochatku XX st. v publitsystytsi ta istoriohrafii. Kharkiv, Kharkov State University Press, 2006, 358 p. (in Ukrainian)

Posokhov S. I. "Schitaiu dlia sebia neprilichnym...": Eticheskie aspekty protsessa zashchity dissertatsii v universitetakh Rossiiskoi imperii XIX - nachala XX v. Kharkivs'kii istoriografichnii zbirnik. Iss. 11. Kharkiv, N. V. Karazin Kharkiv National University Press, 2012, pp. 131-153. (In Russian)

Posokhov S.I. Universitet i gorod v Rossiiskoi imperii (vtoraia polovina XVIII - pervaia polovina XIX v.). Khar'kov, Kharkov State University Press, 2014, 364 p. (In Russian) 
Romanov Iu.V. Nauka i vlast': nasledie L. A. Kasso. Trudy nauchnoi konferentsii studentov i aspirantov "Lomonosov-99". Istoriia. Moscow, Moscow State University, 1999, pp. 76-80. (In Russian)

Rostovtsev E. A. Akademicheskaia korporatsiia Sankt-Peterburgskogo universiteta v nachale XX v.: otnoshenie k vlasti i grazhdanskomu obshchestvu. "Byt' russkim po dukhu i evropeitsem po obrazovaniiu": Universitety Rossiiskoi imperii v obrazovatel'nom prostranstve Tsentral'noi i Vostochnoi Evropy XVIII nachala XX v. Sbornik statei. Moscow, 2009, pp. 139-156. (In Russian)

Rostovtsev E. A. Kazus professora fon Lista (epizod iz universitetskoi istorii perioda Pervoi mirovoi voiny). Uroki istorii - uroki istorika Sbornik statei k 80-letiiu Iu.D. Margolisa. (1930-1996). Eds T. N.Zhukovskaia, A. Iu. Dvornichenko. St. Petersburg, Nestor Istoria, 2012, pp. 308-315. (In Russian)

Rostovtsev E. A. Sankt-Peterburgskii universitet v kontekste sotsial'no-politicheskoi istorii Rossii (1884-1917). Diss. ... dokt. ist. nauk. In 2 vol. St. Petersburg, 2017. Vol. $1-429$ p.; vol. $2-517$ p. (In Russian)

Rostovtsev E.A., Barinov D.A., Krivonozhenko A.V., Sidorchuk I.V. Akademicheskaia korporatsiia stolichnogo universiteta v fokuse istoriografii. KLIO. Zhurnal dlia uchenykh, 2012, no. 7, p. 55. (In Russian)

Sanders T. Tretii opponent: zashchita dissertatsii i obshchestvennyi profil' akademicheskoi istorii v Rossiiskoi imperii. Istoricheskaia kul'tura imperatorskoi Rossii: formirovanie predstavlenii o proshlom. Moscow, National Research University "Higher School of Economics" Press, 2012, pp. 161-192. (In Russian)

Sazonova L. A. Korporativnye otnosheniia professorov Kazanskogo universiteta. Vtoraia polovina XIX veka. Obrazovanie i prosveshchenie v gubernskoi Kazani. Sbornik statei. Iss. 2. Kazan', Istitut istorii Akademii nauk Respubliki Tatarstan, 2009, pp. 169-175. (In Russian)

Sazonova L. A. Povsednevnost' universitetskogo professora Kazani $1863-1917$ gg. Diss. ... kand. ist. nauk. Kazan', 2009, 217 p. (In Russian)

Schiller J. Aleksandr Lwowicz Błok (1852-1909) - portret niespełnionego człowieka i uczonego. Kwartalnik Historii Nauki i Techniki, 2009, no. 1, s. 11-33.

Schiller J. Profesorowie Cesarskiego Uniwersytetu Warszawskiego wobec wydarzeń rewolucji 1905 roku. Rozprawy z Dziejow Oswiaty, 2008, vol. XVII (XLII), s. 75-97.

Schiller J. Universitas rossica. Koncepcja rosyjskiego uniwersytetu 1863-1917. Warszawa, Wydawnictwo IHN PAN, 2008, 709 s.

Sharova A. V. Universitetskoe soobshchestvo i vlast' v nachale XX veka (po materialam dnevnikovykh zapisei A. N. Savina). Vestnik of Russian State University for the Humanities, 2010, no.18, pp. 270-287. (In Russian)

Sharshunov V. A. Istoriia sozdaniia gosudarstvennoi sistemy attestatsii uchenykh i pedagogov v Rossiiskoi imperii. Problemy upravleniia, 2007, no. 3 (24), pp. 74-91. (In Russian)

Shiller-Valitska I. Proekty reformy rossiiskikh universitetov kontsa XIX - nachala XX veka. Istoriia $i$ istoricheskaia pamiat', 2013, no. 7-8, pp. 191-207. (In Russian)

Sosnitskii D. A. Osnovnye napravleniia izucheniia istorii Sankt-Peterburgskogo universiteta v sovremennoi rossiiskoi istoriografii. Klio, 2017, no. 10 (130), pp. 207-217. (In Russian)

Stockdale M. K. Civil Society and Academic Debate in Russia, 1905-1914 by David Wartenweiler [Review]. Russian History, 2000, vol. 27, no. 3, pp. 348-350

Suiazov V. V. Professorskii distsiplinarnyi sud v vuzakh Rossiiskoi Imperii. Vestnik nauki i obrazovaniia. Bulletin of Science and Education, 2015, no. 5 (7), pp. 101-105. (In Russian)

Sveshnikov A. V. "Vot vam istoriia nashei istorii". K probleme tipologii nauchnykh skandalov vtoroi poloviny XIX - nachala XX v. Mir istorika. Iss. 1. Omsk, Omsk State University Press, 2005, pp. 256-260. (In Russian)

Tamul S. Die Bedeutung des Krieges für die Universität Jur'ev: Schließungsabsichten und Evakuierungsmaßnahmen (1915-1918). Kollegen - Kommilitonen - Kämpfer. Europäische Universitäten im Ersten Weltkrieg. Hrsg. von T. Maurer. Stuttgart, Steiner, 2006, S. 223-238.

Tamul S. Donatsioonid Tartu ülikoolile aastatel 1802-1918. Ajalooline Ajakiri, 2002, s. 177-192.

Tamul S. Über die Studentenschaft der russifizierten Tartuer Universität (1883-1918). Universitätsgeschichte in Osteuropa. Stuttgart, Franz Steiner Verlag, 2001, S. 102-111.

Tsygankov D. A. Professor Moskovskogo universiteta V.I. Ger'e (1837-1919). Novaia i noveishaia istoriia, 2002, no. 5, pp. 219-230. (In Russian)

Tsygankov D. A. V.I. Ger'e i Moskovskii universitet ego epokhi (vtoraia polovina XIX - nachalo XX v.). Moscow, St. Tikhon Orthodox Humanitarian University Press, 2008, 256 p. (In Russian)

Vishlenkova E. A. Pamiat' o konfliktakh: osobennosti arkhiva Kazanskogo imperatorskogo universiteta. Ekho vekov, 2008, no. 2, pp. 248-257. (In Russian)

Vishlenkova E. A. Universitetskie ritualy (na materialakh Imperatorskogo Kazanskogo universiteta). Kharkivs'kii istoriografichnii zbirnik. Iss. 7. Kharkiv, N. V. Karazin Kharkiv National University Press, 2004, pp. 4-14. (In Russian) 
Vishlenkova E. A., Malysheva S. Iu. Sal'nikova A. A. Terra Universitatis: Dva veka universitetskoi kul'tury v Kazani. Kazan', Kazan' State University Press, 2005, 500 p. (In Russian)

Vuchinich A. Russkaia nauka v epokhu krizisa: 1890-1910 gg. Voprosy istorii estestvoznaniia i tekhniki, 1993, no. 3, pp. 3-28. (In Russian)

Wartenweiler D. Civil Society and Academic Debate in Russia. 1905-1914. Oxford, 1999. XII, 252 p.

Zagorul'ko E. A. Professorskie distsiplinarnye sudy v vuzakh Sankt-Peterburga (1907-1914 gody). Izbrannye tezisy dokladov III Studencheskoi sotsiologicheskoi mezhvuzovskoi konferentsii. Ed. by M. R. Demin. St. Petersburg, 2012, pp. 28-30. (In Russian)

Zharova E. Iu. Izdavaemye universitetami «Obozreniia prepodavaniia nauk» kak istoricheskii istochnik po istorii vysshego obrazovaniia v dorevoliutsionnoi Rossii. Istoricheskoe obozrenie, 2013, no. 14, pp. 6873. (In Russian)

Zheliaskov S., Levchenko V. Metricheskie knigi Aleksandro-Nevskoi tserkvi Imperatorskogo Novorossiiskogo universiteta kak istochnik biograficheskikh issledovanii ego professorsko-prepodavatel'skogo sostava. Ugo-Zapad. Odessika. Istoriko-kraevedcheskii nauchnyi al'manakh. Iss. 11. Odessa, Pechatnii dom, 2011, pp. 22-34. (In Russian)

Zhukovskaia T. N. Universitety $i$ universitetskie traditsii v Rossii. Kurs lektsii. Petrozavodsk, Petrazovodsk State University Press, 2011, 140 p. (In Russian)

Zmeev V. A. Evoliutsiia vysshei shkoly Rossiiskoi imperii. Moscow, LATMES M, 1998. 242 p. (In Russian)

Zmeev V.A. Universitetskii ustav 1884 g. Sotsial'no-politicheskii zhurnal, 1998, no. 6, pp. 139-154. (In Russian)

Received: May 12, 2018

Accepted: November 30, 2018

Статья поступила в редакцию 12 мая 2018 г.

Рекомендована в печать 30 ноября 2018 г. 